\title{
Analisis Perwilayahan Pembangunan dan Iklim Investasi di Provinsi Bengkulu
}

\author{
${ }^{1}$ YANA TATIANA, ${ }^{2}$ MUHAMMAD FIRDAUS, ${ }^{3}$ HERMANTO SIREGAR, \\ ${ }^{4}$ HIMAWAN HARIYOGA \\ 1) Fakultas Ekonomi, Universitas Azzahra, Jakarta, 2,3) Fakultas Ekonomi dan Manajemen, IPB \\ 4) BKPM, Jakarta \\ email: ${ }^{1}$ yana_tatiana@yahoo.co.id; 2 firdausfemipb@yahoo.com; ${ }^{3}$ hermansiregar@yahoo.com; \\ ${ }^{4}$ himawan.hariyoga@bkpm.go.id
}

\begin{abstract}
Sustainable Economic growth in the long run be a development goal. Development that is driven by the growth of investment will create sustainability. Local governments use many methods in promoting the region to attract investment. This paper aims to analyze the factors affect the investment climate as well as determine sectors driving the success of development in the province of Bengkulu (9 counties and one city) by using Quotients Klassen, Location quation (LQ), shiftshare, fiscal capacity and regression. This study concluded that areas which have base sector in agricultural capable of developing and developed despite its ability to attract FDI and domestic investment is relatifly low. While the areas natural resources such as mining become center of domestic and foreign investment, was not able to develop into advanced and fast growing areas. Ownership of land and infrastructure becomes the dominant factor affecting the investment climate in the Province of Bengkulu
\end{abstract}

Keyword : regional investment, climate investment, regional development

\begin{abstract}
Abstrak. Pertumbuhan Ekonomi yang berkelanjutan dalam jangka panjang menjadi tujuan Pembangunan. Pencapaian keberhasilan pembangunan yang didorong oleh pertumbuhan investasi akan menciptakan keberlanjutan. Berbagai cara dilakukan oleh Pemerintah daerah dalam mempromosikan daerahnya untuk menarik investasi ke wilayahnya. Makalah ini bertujuan untuk menganalisis faktor-faktor yang mempengaruhi iklim investasi sekaligus menentukan sektor-sektor pendorong keberhasilan pembangunan di Propinsi Bengkulu. Penelitian ini dilakukan di 9 kabupaten dan 1 kota dengan menggunakan analisis Tipologi klassen, Location Quation (LQ), shiftshare, kapasitas fiscal dan regresi logistik. Penelitian ini menyimpulkan bahwa wilayah-wilayah yang menjadikan sektor pertanian sebagai sektor basis yang mampu berkembang dan maju walaupun kemampuannya dalam menarik PMA dan PMDN relatif rendah. Sedangkan wilayah-wilayah yang memiliki kekayaan Sumber daya alam berupa hasil tambang, menjadi pusat PMA dan PMDN ternyata tidak mampu berkembang menjadi wilayah yang bertumbuh secara maju dan cepat. Kepemilikan lahan dan infrastruktur daerah menjadi faktor dominan yang mempengaruhi iklim investasi di Propinsi Bengkulu.
\end{abstract}

Kata Kunci : investasi wilayah, iklim investasi, pembangunan wilayah.

\section{Pendahuluan}

Reformasi sistem pemerintahan yang terjadi saat ini menyebabkan pergeseran orientasi pembangunan daerah dari pembangunan yang berorientasi sektoral menuju pengembangan wilayah. Pembangunan berbasis pengembangan wilayah memandang pentingnya keterpaduan intersektoral, interspasial serta antar pelaku pembangunan di dalam dan antar daerah.

Pembangunan merupakan serangkaian kegiatan yang berkesinambungan selaras dengan intensitas dan aktivitas masyarakat dan pemerintah. Pertumbuhan ekonomi yang berkelanjutan merupakan kondisi utama bagi kelangsungan pembangunan ekonomi daerah.

Pengejaran petumbuhan merupakan tema sentral dalam kehidupan ekonomi

Received: 25 Maret 2015, Revision: 15 Oktober 2015 2015, Accepted: 27 Desember 2015

Print ISSN: 0215-8175; Online ISSN: 2303-2499. Copyright@2015. Published by Pusat Penerbitan Universitas (P2U) LPPM Unisba Terakreditasi SK Kemendikbud, No.040/P/2014, berlaku 18-02-2014 s.d 18-02-2019 
Tabel 1

Perkembangan PMA dan PMDN di Provinsi Bengkulu (1968- 2013)

\begin{tabular}{|c|c|c|c|c|c|}
\hline \multirow[b]{2}{*}{ Sektor Ekonomi } & \multirow[b]{2}{*}{ Sub Sektor } & \multicolumn{2}{|l|}{ PMDN } & \multicolumn{2}{|l|}{ PMA } \\
\hline & & LKPM & $\begin{array}{l}\text { Nilai Modal } \\
\text { (Miliar } \\
\text { rupiah) }\end{array}$ & LKPM & $\begin{array}{l}\text { Nilai Modal } \\
\text { (Miliar } \\
\text { rupiah) }\end{array}$ \\
\hline \multirow[t]{3}{*}{ Primer } & & 17 & 1336 & 12 & 1124 \\
\hline & Perkebunan & 12 & 1199 & 8 & 1023 \\
\hline & Pertambangan & 5 & 167 & 4 & 100 \\
\hline \multirow[t]{2}{*}{ Sekunder } & & 6 & 277 & 6 & 343 \\
\hline & Industri & 6 & 614 & 6 & 343 \\
\hline \multirow[t]{4}{*}{ Tersier } & & 10 & 2502 & 8 & 22 \\
\hline & Listrik & 1 & 417 & 0 & 0 \\
\hline & Jasa & 3 & 2085 & 6 & 8.8 \\
\hline & Perdagangan & 0 & 0 & 2 & 13 \\
\hline
\end{tabular}

Sumber : LKPM tahun 2013

Tabel 2

Realisasi investasi menurut Kabupaten/Kota berdasarkan LKPM s.d. November 2013

\begin{tabular}{|l|c|c|c|c|}
\hline \multirow{2}{*}{ Kabupaten/Kota } & \multicolumn{2}{|c|}{ PMDN } & \multicolumn{2}{c|}{ PMA } \\
\cline { 2 - 5 } & LKPM & $\begin{array}{c}\text { Investasi } \\
\text { (Miliar Rp) }\end{array}$ & LKPM & $\begin{array}{c}\text { Investasi } \\
\text { (Miliar Rp) }\end{array}$ \\
\hline Mukomuko & 3 & 440 & 6 & 705 \\
\hline Bengkulu Utara & 8 & 761 & 9 & 446 \\
\hline Kaur & 0 & 0 & 1 & 188 \\
\hline Lebong & 1 & 416 & 2 & 9.2 \\
\hline Bengkulu Selatan & 0 & 0 & 0 & 0 \\
\hline Bengkulu Tengah & 5 & 320 & 3 & 114 \\
\hline Kepahiang & 0 & 0 & 1 & 7.7 \\
\hline Rejang Lebong & 0 & 0 & 0 & 4,1 \\
\hline Seluma & 5 & 128 & 1 & 14,1 \\
\hline Kota Bengkulu & 5 & 2085 & 3 & 1448.6 \\
\hline TOTAL & 27 & 4145 & 26 & 0 \\
\hline
\end{tabular}

Sumber : BKPMD Prov. Bengkulu 2014

wilayah, tidak terkecuali Propinsi Bengkulu. Propinsi Bengkulu adalah propinsi yang ada di bagian barat Pulau Sumatera yang memiliki PDRB dan pertumbuhan ekonomi terendah diantara seluruh Provinsi di Pulau Sumatera, dan peringkat lima terbawah dalam skala nasional. Rendahnya tingkat PDRB ini mengindikasikan masih tertinggalnya proses pembangunan di Provinsi Bengkulu, kondisi ini dapat juga mengindikasikan banyaknya permasalahan pembangunan yang harus yang dibenahi.

Pembangunan ekonomi harus didukung oleh berbagai faktor diantaranya investasi. Pembangunan yang didukung oleh peningkatan investasi akan mendorong keberlanjutan hasil pembangunan (Mankiw, 2007). Peningkatan investasi wilayah tidak terlepas dari iklim investasi wilayah. Untuk menciptakan iklim investasi yang kondusif, tidak terlepas dari peranan Pemerintah Daerah (KPPOD, 2012). Banyak hal yang harus dilakukan untuk mencapai keberhasilan pembangunan tidak hanya melalui peranan pemerintah. Menurut (Duadji, 2012), tidak ada satu pun tujuan pembangunan yang dapat diwujudkan dengan baik hanya dengan mengubah karakteristik dan cara kerja institusi dan pemerintah.

Provinsi Bengkulu memiliki kemampuan yang rendah untuk menarik investor. 
Banyak hal menjadi penyebab rendahnya minat investor masuk ke Provinsi Bengkulu diantaranya perizinan yang relatif sulit, infrastruktur yang kurang memadai, jalur transportasi yang terbatas, rendahnya fasilitas di bandara maupun pelabuhan.

Berdasarkan hasil pemetaan wilayah yang dilakukan oleh Master Plan percepatan Pembangunan Ekonomi Indonesia (MP3EI) memperlihatkan bahwa Propinsi Bengkulu relatif terisolasi dibandingkan Propinsi lain yang ada di Pulau Sumatera, dikarenakan tidak berada di jalur lintasan utama, sehingga relatif sulit menarik investor untuk masuk ke wilayah ini. Hal ini terlihat dari rendahnya jumlah investor yang masuk ke Provinsi Bengkulu dalam rentang waktu 1968-2013 (Tabel 1)

Tabel 1 memerlihatkan Laporan kegiatan penanaman modal yang dikeluarkan oleh Badan koordinasi Penanaman Modal Daerah (BKPMD) Provinsi Bengkulu periode 19682013. Terlihat bahwa penanaman modal baik dalam negeri maupun luar negeri di Propinsi Bengkulu masih di dominasi oleh sektor primer pada subsektor perkebunan dan pertambangan. Adapun realisasi investasi menurut daerah adalah sebagai berikut:

Tabel 2 memerlihatkan bahwa dari seluruh kabupaten yang ada di Propinsi Bengkulu, kabupaten yang banyak memiliki PMA dan PMDN adalah Kota Bengkulu, Bengkulu Utara dan Mukomuko. Sedangkan Kabupaten Bengkulu Selatan dan Rejang Lebong tidak memiliki PMA dan PMDN yang tercatat di LKPM BKPMD Propinsi Bengkulu. Hal ini dapat diasumsikan adanya perbedaan kemampuan daerah dalam menarik investor ke daerahnya. Kemampuan daerah ini sangat tergantung pada daya tarik yang dimiliki dan kemampuan pengelola daerah dalam memasarkan daerahnya.

Keberhasilan daerah untuk meningkatkan daya tarik investasinya sangat tergantung dari kebijakan yang berkaitan dengan investasi, Selain itu, kemampuan daerah untuk menentukan faktor-faktor yang dapat digunakan sebagai alat ukur daya saing perekonomian daerah relatif terhadap daerah lainnya juga penting terkait dengan pengembangan sumberdaya manusia dan infrastruktur fisik dalam upaya meningkatkan daya tariknya dan memenangkan persaingan (KPPOD, 2003).

Peningkatan daya saing daerah adalah salah satu faktor pengembangan (ekonomi) wilayah. Pengembangan wilayah dilaksanakan sesuai dengan prinsip-prinsip otonomi dan desentralisasi. Pemerintah Daerah mempunyai wewenang penuh dalam mengembangkan kelembagaan pengelolaan ekonomi di daerah, sumberdaya manusianya, iklim usaha yang dapat menarik modal dan investasi, peran aktif swasta dan masyarakat melalui koordinasi terus-menerus dengan seluruh stakeholder pembangunan, baik di daerah dan pusat.Pemerintah Daerah berperan sebagai fasilitator dan katalisator bagi tumbuhnya minat investasi di wilayahnya.

Berdasarkan Laporan akhir pengkinian Buku Profil dan Pemetaan Daya Saing Ekonomi Daerah Kabupaten Kota di Indonesia tahun 2012, dinyatakan bahwa hal utama yang mengakibatkan rendahnya daya saing daerah adalah basis perekonomiannya yang masih sangat tergantung pada sektor primer, belanja pelayanan publik yang cukup besar, kondisi geografis yang kurang menguntungkan dan kurang menarik minat dunia usaha.

Rendahnya tingkat investasi di Propinsi Bengkulu dibandingkan propinsi-propinsi lain yang ada di Indonesia, mengindikasikan perlunya kebijakan Pemerintah yang mampu menciptakan iklim usaha yang dibutuhkan oleh para pelaku ekonomi untuk melakukan aktivitasnya

Tujuan penulisan ini adalah menganalisis kondisi di Propinsi Bengkulu dalam kaitannya dengan struktur ekonomi, pola pertumbuhan dan penentuan sektor basis dalam kaitan antar wilayah. Memahami faktor penentu yang menjadi daya tarik investor untuk menanamkan modalnya di Propinsi ini.

\section{Tinjauan Pustaka}

Menurut Isard (1975) dalam Rustiadi (2009), pengertian suatu wilayah pada dasarnya bukan sekadar areal dengan batas-batas tertentu. Wilayah adalah suatu area yang memiliki arti (meaningful) karena adanya masalah-masalah yang ada di dalamnya sedemikian rupa. Murty (2000) mendefinisikan wilayah sebagai suatu area geografis, teritorial, atau tempat, yang dapat berwujud sebagai suatu negara, provinsi, distrik (kabupaten), dan perdesaan.

Tapi suatu wilayah pada umumnya tidak sekadar merujuk suatu tempat atau area, melainkan merupakan suatu kesatuan ekonomi, politik, sosial, administrasi, iklim, hingga geografis, sesuai dengan pembangunan atau kajian. 
Pembangunan harus dipandang sebagai suatu proses multidimensional yang mencakup berbagai perubahan mendasar atas struktur sosial, sikap masyarakat, dan institusi-institusi nasional, di samping tetap mengejar akselerasi pertumbuhan ekonomi, penanganan ketimpangan pendapatan, serta pengentasan kemiskinan, sehingga dapat disimpulkan bahwa pembangunan merupakan suatu kenyataan fisik sekaligus tekad masyarakat untuk berupaya sekeras mungkin (melalui serangkaian kombinasi proses sosial, ekonomi dan institusional) demi mencapai kehidupan yang serba lebih baik (Todaro dan Stephen, 2006).

Pembangunan ekonomi daerah adalah suatu proses dimana pemerintah daerah dan seluruh komponen masyarakat mengelola berbagai sumber daya yang ada dan membentuk suatu pola kemitraan untuk menciptakan suatu lapangan pekerjaan baru dan merangsang perkembangan kegiatan ekonomi dalam daerah tersebut (Lincolin Arsyad, 1999; Blakely E. J, 1989).

Tolok ukur keberhasilan pembangunan dapat dilihat dari pertumbuhan ekonomi, struktur ekonomi dan semakin kecilnya ketimpangan pendapatan antarpenduduk, antardaerah dan antarsektor. Suatu ekonomi dikatakan mengalami pertumbuhan yang berkembang apabila tingkat kegiatan ekonominya lebih tinggi daripada apa yang dicapai pada masa sebelumnya. Pertumbuhan ekonomi adalah proses kenaikan output per kapita dalam jangka panjang.

Pertumbuhan ekonomi di suatu negara/ daerah tidak lagi hanya dipengaruhi oleh faktor kapital dan tenaga kerja saja, tetapi juga terdapat faktor lain seperti teknologi yang menjadi faktor penentu dalam pembentukan output (Romer, 2006). Investasi merupakan salah satu faktor dalam berbagai teori pembangunan yang merupakan penggerak atau akselerator pertumbuhan ekonomi dan peningkatan pendapatan masyarakat. Investasi merupakan kombinasi antara tingkat permintaan untuk berinvestasi dari perusahaan dengan tabungan (saving) dari rumah tangga (Romer 2006).

Artikel ini menggunakan beberapa metode analisis yang dikelompokkan ke dalam dua kelompok analisis yaitu analisis deskriptif dan eksposisi. Analisis deskriptif meliputi: (1) Analisis Tipologi Klassen yang digunakan untuk mengetahui gambaran pola dan struktur pertumbuhan ekonomi daerah (Priyarsono, Sahara, Firdaus 2007); (2) Analisis Location Quotient (LQ) yang digunakan untuk mengidentifikasi komoditas unggulan diakomodasi dari Miller \& Wright (1991), Isserman (1997), dan Ron Hood (1998). metode ini memiliki bentuk persamaan sebagai berikut:

$$
L Q=\frac{v i / v t}{V i / V t}
$$

dimana LQ adalah Location Quotient, $\mathrm{v}_{\mathrm{i}}$ adalah output sektor i di suatu daerah, $V_{i}$ adalah output sektor i nasional, $\mathrm{v}_{\mathrm{t}}$ adalah output total daerah tersebut, $\mathrm{V}_{\mathrm{t}}$ adalah output total nasional. Jika LQ $<1$ sektor tersebut memiliki potensi yang kecil untuk menjadi sektor basis wilayah; LQ = 1 : sektor tersebut telah mampu memenuhi kebutuhan lokalnya dan dapat berpotensi sebagai kegiatan basis ekonomi wilayah; LQ > 1: sektor tersebut merupakan sektor basis ekonomi wilayah; (3) Analisis shift-share (S-S) yang digunakan untuk memproyeksikan pertumbuhan ekonomi suatu daerah dan sebagai analisis di dalam riset pembangunan pedesaan. (4) Kapasitas Fiskal yang digunakan untuk menggambarkan kemampuan keuangan suatu daerah provinsi/kabupaten/kota dalam membiayai pembangunannya. Perhitungan kapasitas fiskal setiap daerah didasarkan pada formula berikut (Keputusan Menteri Keuangan No. 538/KMK.07/2003):

$$
K \boldsymbol{F}=\frac{(P A D+B H+D A U+P L)-B P}{\text { Jumlahpendudukmiskin }}
$$

dimana : $\mathrm{KF}=$ kapasitas fiskal, $\mathrm{PAD}=$ pendapatan asli daerah, $\mathrm{BH}=$ Bagi hasil pajak dan bagi hasil bukan pajak (sumberdaya alam), DAU=dana alokasi umum, $\mathrm{P}=$ penerimaan lain-lain yang sah, kecuali dana alokasi khusus, dana darurat, dana pinjaman lama, dan penerimaan lainnya yang dibatasi penggunaannya. $\mathrm{BP}=$ belanja pegawai. Kapasitas fiskal dikelompokkan menjadi tiga kelompok, yaitu: (decile) 1 dan 2 kategori daerah kapasitas fiskal tinggi; (decile) 3, 4, dan 5 kategori daerah kapasitas fiskal sedang, (decile) 6, 7, 8, 9, dan 10 kategori daerah kapasitas fiskal rendah.

Untuk mengetahui tingkat kemampuan finansial dari masing-masing kabupaten dan kota dalam membiayai kebutuhan anggaran belanja daerahnya serta perbandingannya dengan peranan sumbangan dan bantuan yang diberikan oleh Pemerintah Pusat kepada Pemerintah Daerah atau yang disebut dengan Derajat Desentralisasi Fiskal (Sumarsono, 2009) dengan rumus:

$\frac{\text { Pendapatan Asli Daerah (PAD) }}{\text { Total Penerimaan Daerah (TPD) }}$

Analisis eksposisi yang digunakan adalah regresi logistik. Analisis regresi logistik 
digunakan karena variabel terikat adalah data kategori (Juanda, 2009). Kategori yang dipergunakan yaitu $Y=1$ jika iklim investasi kondusif dan $Y=0$ jika iklim investasi tidak kondusif. Model ini dipilih untuk menganalisis keputusan dan menentukan probabilita terkait dengan pilihan dalam pengembangan iklim investasi. Tabel 3 menggambarkan variabel penjelas yang digunakan berikut skala yang digunakan.

\section{Tabel 3}

Variabel dalam Model Regresi Logistik

\begin{tabular}{|l|l|l|l|}
\hline Variabel & Deskripsi & Skala & Slope \\
\hline LHN & Kemudahan & Ordinal & $\beta_{1}$ \\
\hline INF & Ketersediaan & Ordinal & $\beta_{2}$ \\
\hline IZ & Proses & Ordinal & $\beta_{3}$ \\
\hline PD & $\begin{array}{c}\text { Peraturan } \\
\text { daerah }\end{array}$ & Ordinal & $\beta_{4}$ \\
\hline TC & Biaya & Ordinal & $\beta_{5}$ \\
\hline
\end{tabular}

Proses pengumpulan data menggunakan kuesioner tertutup, jawaban pertanyaannya menggunakan skala Likert antara 1-5, dimana 1 jika menyatakan sangat tidak setuju/sangat buruk; 2 jika menyatakan tidak setuju/buruk, 3 jika menyatakan raguragu; 4 jika menyatakan setuju/baik, dan 5 jika menyatakan sangat setuju/sangat baik. Kuesioner ini disebarkan pada 33 perusahaan yang meliputi PMA dan PMDN yang ada di Propinsi Bengkulu.

\section{Analisis Perwilayahan}

Bengkulu adalah propinsi yang ada di pesisir barat Pulau Sumatera, yang terdiri atas 9 kabupaten dan 1 kota yaitu kabupaten Bengkulu Selatan, Rejang Lebong, Bengkulu Utara, Kepahiang, Lebong, Bengkulu Tengah, Seluma, Kaur, Muko-Muko, dan Kota Bengkulu. Pada awalnya, Provinsi ini hanya terbentuk dari tiga kabupaten induk yaitu Bengkulu Utara, Bengkulu Selatan, dan Rejang Lebong, beserta satu kota yaitu Kota Bengkulu. Seiring dengan kebijakan pemekaran wilayah, Kabupaten Bengkulu Selatan dimekarkan menjadi 3 kabupaten meliputi Seluma, Bengkulu Selatan dan Kaur. Bengkulu Utara dimekarkan menjadi 3 kabupaten meliputi Bengkulu Utara, Mukomuko dan Bengkulu Tengah. Kabupaten Rejang Lebong dimekarkan juga menjadi 3 kabupaten meliputi Kepahiang, Lebong dan Rejang Lebong. Hanya Kota Bengkulu yang tidak mengalami pemekaran dan menjadi ibukota Provinsi.

Perkembangan dari masing-masing kabupaten ini memerlihatkan pola pertumbuhan yang berbeda, walaupun struktur perekonomiannnya masih sangat didominasi oleh kabupaten induk. Beberapa kabupaten mampu berkembang pesat yang ditandai dengan tingginya tingkat pendapatan perkapita dan laju pertumbuhan ekonomi, tetapi masih terdapat juga kabupaten yang perkembangan ekonominya masih tersendat ditandai dengan rendahnya tingkat pendapatan perkapita dan laju pertumbuhan ekonomi.

\begin{abstract}
Menurut Tolo (J.Tolo, 2011), faktor yang memengaruhi pertumbuhan ekonomi di suatu wilayah adalah inflasi, perdagangan antara wilayah, ekspor pertanian, investa$\mathrm{si}$, pertumbuhan penduduk dan ketidakpastian politik. Tingkat pertumbuhan GDP dan ekspor secara signifikan akan menstimulasi investasi domestik, akan tetapi FDI dan pertumbuhan sumber daya manusia hanya mampu menstimulasi investasi dalam jangka panjang (Al Khatib, 2005).
\end{abstract}

Adapun penyebaran pertumbuhan ekonomi dan pendapatan per kapita seluruh kabupaten dan kota yang dianalisis dengan menggunakan tipologi klassen pada Gambar 1 berikut:

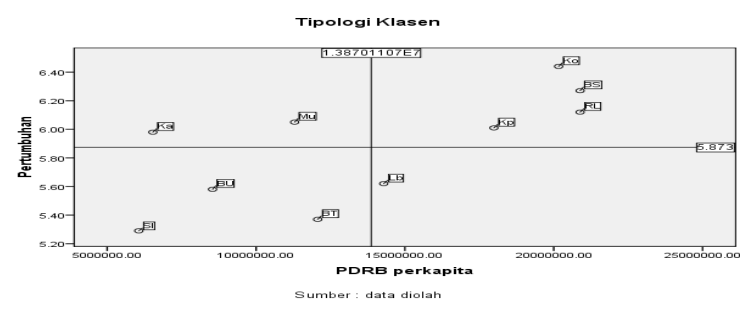

Gambar 1

Tipologi Klasen Wilayah Kabupaten dan Kota

Berdasarkan analisis tipologi klassen diketahui bahwa hanya empat kabupaten yang memiliki pertumbuhan dan pendapatan per kapita tinggi yaitu Kepahiang, Bengkulu Selatan, Rejang Lebong, dan Kota Bengkulu. Bahkan, masih ada kabupaten yang memiliki tingkat pertumbuhan dan pendapatan per kapita rendah, yaitu Seluma, Bengkulu Utara, dan Bengkulu Tengah.

Perbedaan tingkat pertumbuhan ekonomi dan pendapatan per kapita antar wilayah dipengaruhi oleh banyak hal, antara lain jumlah penduduk, aktivitas atau jenis pekerjaan masyarakat, sumber daya alam yang dimiliki, dan sektor ekonomi yang mendominasi wilayah tersebut. Wilayah yang 
mampu memenuhi kebutuhannya sekaligus menjadi produsen bagi wilayah lain akan menjadi wilayah yang memiliki multiflier efek yang besar.

Kemampuan wilayah dalam menghasilkan barang dan jasa, baik untuk pasar lokal maupun luar daerah, akan mendorong peningkatan pendapatan masyarakat di wilayah tersebut. Sektor yang mampu menghasilkan barang atau jasa untuk pasar dalam maupun luar wilayah disebut dengan sektor basis. Sektor-sektor perekonomian basis dan non basis akan mendorong perbedaan tingkat pertumbuhan dan corak perekonomian wilayah. Di Provinsi Bengkulu, beberapa kabupaten memiliki sektor basis seperti diuraikan pada Tabel 4.

Kota Bengkulu sebagai ibukota propinsi selain memiliki tingkat pendapatan tertinggi juga menjadi wilayah yang memiliki sektor basis terbanyak di Provinsi Bengkulu. Banyaknya sektor basis yang dimiliki suatu wilayah mengindikasikan tingginya kemampuan daya saingnya di antara wilayah lain yang ada di Propinsi Bengkulu.

Kabupaten Bengkulu Utara dan Bengkulu Selatan tidak lagi menjadikan Pertanian sebagai sektor basis. Sedangkan kondisi yang ada di Kabupaten Bengkulu Utara dan Bengkulu Selatan memerlihatkan bahwa hasil perkebunan besar swasta maupun perkebunan

Tabel 4

Analisis Sektor Basis dan Kemampuan Pembiayaan Wilayah

\begin{tabular}{|c|c|c|c|c|}
\hline Kab/Kota & $\begin{array}{l}\text { Location Quatient } \\
\text { (Sektor basis) }\end{array}$ & $\begin{array}{c}\text { Shiftshare } \\
\text { (Pertumbuhan } \\
\text { sektoral) } \\
\end{array}$ & Tipolog Klasen & $\begin{array}{c}\text { Kapasitas } \\
\text { Fiskal }\end{array}$ \\
\hline Bengkulu Selatan & $\begin{array}{c}\text { Jasa } \\
\text { Perdagangan } \\
\text { Konstruksi } \\
\text { Transportasi }\end{array}$ & $\begin{array}{c}\text { Lambat } \\
\text { Lambat } \\
\text { Cepat } \\
\text { Lambat }\end{array}$ & $\begin{array}{c}\text { Potensial } \\
\text { Potensial } \\
\text { Maju } \\
\text { Maju }\end{array}$ & Sedang \\
\hline Rejang Lebong & Pertanian & Lambat & Maju & Sedang \\
\hline Bengkulu Utara & $\begin{array}{c}\text { Pertambangan } \\
\text { Konstruksi } \\
\text { Jasa }\end{array}$ & $\begin{array}{l}\text { Lambat } \\
\text { Cepat } \\
\text { Cepat }\end{array}$ & $\begin{array}{l}\text { Maju } \\
\text { Maju } \\
\text { Maju }\end{array}$ & Sedang \\
\hline Kaur & $\begin{array}{c}\text { Konstruksi } \\
\text { Transportasi } \\
\text { Pertanian }\end{array}$ & $\begin{array}{c}\text { Maju } \\
\text { Lambat } \\
\text { Lambat }\end{array}$ & $\begin{array}{c}\text { Maju } \\
\text { Maju } \\
\text { Terhambat }\end{array}$ & Tinggi \\
\hline Seluma & $\begin{array}{c}\text { Pertanian } \\
\text { Konstruksi } \\
\text { Pertambangan }\end{array}$ & $\begin{array}{l}\text { Lambat } \\
\text { Cepat } \\
\text { Lambat }\end{array}$ & $\begin{array}{c}\text { Maju } \\
\text { Maju } \\
\text { Potensial }\end{array}$ & Sedang \\
\hline Muko-muko & $\begin{array}{c}\text { Industri pengolahan } \\
\text { Keuangan } \\
\text { Pertanian } \\
\end{array}$ & $\begin{array}{l}\text { Lambat } \\
\text { Cepat } \\
\text { Lambat }\end{array}$ & $\begin{array}{c}\text { Maju } \\
\text { Maju } \\
\text { Potensial } \\
\end{array}$ & Tinggi \\
\hline Lebong & Pertanian & Lambat & Maju & Tinggi \\
\hline Kepahiang & Pertanian & Lambat & Maju & Tinggi \\
\hline Bengkulu Tengah & $\begin{array}{c}\text { Pertambangan } \\
\text { Industri Pengolahan } \\
\text { Konstruksi } \\
\end{array}$ & $\begin{array}{c}\text { Lambat } \\
\text { Lambat } \\
\text { Cepat }\end{array}$ & $\begin{array}{l}\text { Maju } \\
\text { Maju } \\
\text { Maju } \\
\end{array}$ & Tinggi \\
\hline Kota Bengkulu & $\begin{array}{c}\text { Transportasi dan } \\
\text { komunikasi } \\
\text { Perdagangan } \\
\text { Keuangan } \\
\text { Jasa } \\
\text { Listrik, gas dan air } \\
\text { bersih }\end{array}$ & $\begin{array}{l}\text { Cepat } \\
\text { Cepat } \\
\text { Cepat } \\
\text { Cepat } \\
\text { Lambat } \\
\text { Lambat }\end{array}$ & $\begin{array}{c}\text { Maju } \\
\text { Maju } \\
\text { Maju } \\
\text { Maju } \\
\text { Maju } \\
\text { Potensial }\end{array}$ & Rendah \\
\hline
\end{tabular}


rakyat dengan komoditas unggulan kelapa sawit, karet dan kelapa menjadi salah satu sumber pendapatan terbesar di kedua wilayah ini. Beberapa desa di kabupaten Bengkulu Selatan yang pendapatan masyarakatnya meningkat seiring dengan alih fungsi lahan pertanian mereka dari penghasil bahan makanan menjadi perkebunan kelapa sawit. Beberapa survey menyatakan bahwa aktivitas perkebunan rakyat ini meningkat setelah adanya pabrik pengolahan kelapa sawit. Dengan kata lain investasi industri pertanian akan mampu mendorong pertumbuhan perekonomian masyarakat jika didukung oleh industri pengolahan hasil pertanian.

Hal menarik untuk diamati adalah Kabupaten Bengkulu Utara dengan hasil sektor pertambangan batubara yang terbesar di Propinsi Bengkulu dan jumlah PMA dan PMDN terbanyak di Propinsi Bengkulu, ternyata tidak mampu meningkatkan pertumbuhan ekonomi dan pendapatan per kapita masyarakatnya (Gambar 1). Hal ini juga terjadi di dua kabupaten lain yang memiliki keunggulan di sektor pertambangan.

Kabupaten Lebong merupakan satusatunya kabupaten di Propinsi Bengkulu yang 70-75\% wilayahnya meliputi kawasan hutan lindung dan konservasi, sedangkan hutan produksi yang dimiliki kabupaten ini hanya memiliki luasan yang sangat tidak memadai sebagai sumber pendapatan, sehingga aktivitas ekonomi yang akan mengeksploitasi hutan seperti pembukaan areal tambang dan perkebunan sulit untuk dilakukan di wilayah ini. Hal ini menyebabkan tingkat pertumbuhan ekonomi Kabupaten Lebong relatif rendah.

Kabupaten Seluma sebagai kabupaten pemekaran dari Bengkulu Selatan yang memiliki keunggulan di bidang pertambangan dan perkebunan, ternyata kurang mampu berkembang, ditandai dengan rendahnya tingkat pertumbuhan ekonomi dan PDRB per kapita masyarakatnya. Ditambah lagi dalam 3 tahun terakhir telah terjadi konflik di kalangan Pemerintah Daerah dalam hal penggantian kepala daerah, sehingga menjadi kendala dalam perkembangan iklim berusaha di kabupaten ini.

Kabupaten Bengkulu Tengah dan Mukomuko juga telah mampu menjadikan industri pengolahan sebagai sektor unggulan. Dari seluruh kabupaten yang ada di Propinsi Bengkulu, hanya Kabupaten Muko-muko dan Bengkulu Tengah yang memiliki keunggulan di industri pengolahan. Jenis industri yang menjadi unggulan di kedua kabupaten ini masih didominasi oleh industri makanan, pakaian dan pengolahan hasil alam.

Jika diamati dari sisi perkembangan ekonomi, Mukomuko memiliki tingkat pertumbuhan ekonomi yang lebih tinggi dibandingkan Bengkulu Utara dan Bengkulu Tengah. Walaupun tingkat PDRB per kapitanya masih di bawah Bengkulu Tengah, Mukomuko masih menjadikan pertanian sebagai sektor unggulannya di sektor perkebunan seperti kelapa sawit dan karet (Tabel 4).

Dari seluruh kabupaten/ kota yang ada di Propinsi Bengkulu, hanya Kota Bengkulu, Kabupaten Bengkulu Selatan, dan Kaur yang mampu menjadikan sektor transportasi sebagai sektor basis. Sektor transportasi yang menjadi sektor basis sejalan dengan jalur lintas barat Sumatera yang menghubungkan ketiga kabupaten ini.

Temuan menarik di sini, ternyata beberapa Kabupaten di Propinsi Bengkulu yang memiliki sektor basis di bidang pertanian, memiliki kemampuan yang sangat rendah di sektor pertambangan.

Berdasarkan uraian sebelumnya, maka dapat dinyatakan di Propinsi Bengkulu, sektor pertanian belum dapat ditinggalkan peranannya dalam pencapaian peningkatan pendapatan masyarakat dan pertumbuhan ekonomi, sedangkan kekayaan tambang di suatu wilayah tidak mampu mendorong pertumbuhan ekonomi jika hanya menjadikan wilayah tersebut sebagai lokasi eksploitasi atau backwash bagi pusat pertumbuhan. Keberadaan sektor basis ini akan menarik PMA dan PMDN untuk masuk ke suatu wilayah.

Menurut (Soelistijo, 2011), selain manfaat finansial, manfaat nonfinansial dari perusahaan PMA bagi kepentingan nasional, antara lain, akan mendorong pengembangan wilayah, baik fisik (prasarana dan sarana) maupun non fisik (sosiokultural) termasuk pengembangan masyarakat; dan budaya wirausaha (bisnis) dimana masyarakat setempat melayani kebutuhan akhir (final demand linkages) dari perusahaan. Peningkatan pendapatan suatu wilayah yang dapat diindikasikan sebagai peningkatan konsumsi masyarakat berpengaruh pada tingkat investasi swasta (Karagol, 2004).

Selain keunggulan yang dimiliki dalam bentuk sektor basis. Hal lain yang juga harus diperhatikan adalah kemampuan wilayah dalam membiayai aktivitas pembangunan wilayahnya atau dikenal dengan istilah kapasitas fiskal atau desentralisasi fiskal.

Adapun rasio antara desentralisasi fiskal dan sumbangan atau bantuan pemerintah pusat dari masing-masing kabupaten kota di Propinsi Bengkulu terlihat pada Gambar 
2 berikut:

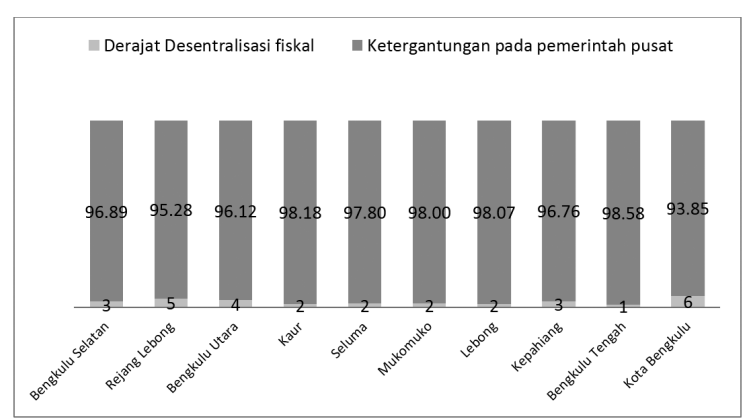

Gambar 2

Derajat Desentralisasi Fiskal seluruh Kabupaten/ Kota di Propinsi Bengkulu

Berdasarkan Gambar 2 terlihat bahwa hampir seluruh kabupaten memiliki derajat desentralisasi fiskal yang sangat rendah, yaitu di bawah 5 persen.Jika hal ini terjadi, berarti ketergantungan pada bantuan pemerintah pusat mencapai di atas 95 persen. Hanya Kota Bengkulu yang memiliki derajat desentralisasi fiskal sebesar 6\% (ketergantungan pada bantuan pemerintah pusat $94 \%$ ). Dengan demikian, dapat dinyatakan bahwa perekonomian di Propinsi Bengkulu masih sangat tergantung pada bantuan dan sumbangan dari Pemerintah Pusat.

Untuk mengetahui kemampuan keuangan suatu daerah provinsi/kabupaten/ kota dalam membiayai pembangunannya dipergunakan alat ukur kapasitas fiskal. Berdasarkan hasil analisis pada Tabel 4, ternyata kabupaten yang relatif sudah lebih dulu berada di Propinsi Bengkulu (kabupaten induk) yaitu Rejang lebong, Bengkulu Utara, dan Bengkulu Selatan, hanya memiliki kapasitas fiskal yang sedang, bahkan Kota Bengkulu sebagai ibukota propinsi dan pusat pertumbuhan di Propinsi Bengkulu, ternyata hanya memiliki kapasitas fiskal rendah.

Hal sebaliknya terjadi di kabupaten yang baru dimekarkan seperti Kaur, Mukomuko, Kepahiang, Lebong, dan Bengkulu Tengah memiliki kapasitas fiskal tinggi. Di antara seluruh kabupaten baru hasil pemekaran, hanya kabupaten Seluma yang memiliki kapasitas fiskal sedang.Tinggi/rendahnya kapasitas fiskal ini tidak semata dikarenakan wilayah tersebut memiliki kemampuan ekonomi yang tinggi, tetapi juga dapat disebabkan oleh rendahnya jumlah penduduk miskin yang ada di wilayah tersebut. Diantara seluruh propinsi yang di Indonesia, Propinsi Bengkulu ternyata memiliki kapasitas fiskal yang rendah. Hal ini dikarenakan kemampuan ekonomi propinsi Bengkulu yang relatif rendah (PAD).

Komponen pembentuk kapasitas fiskal adalah Pendapatan Asli Daerah (PAD), dana perimbangan dari Pemerintah daerah berupa DAU dan DAK dan tingkat kemiskinan. Berdasarkan pengamatan pada seluruh kabupaten/kota di Propinsi Bengkulu, ternyata ada beberapa kabupaten yang memiliki tingkat PAD dibawah garis kemiskinan, seperti terlihat pada Gambar 3.

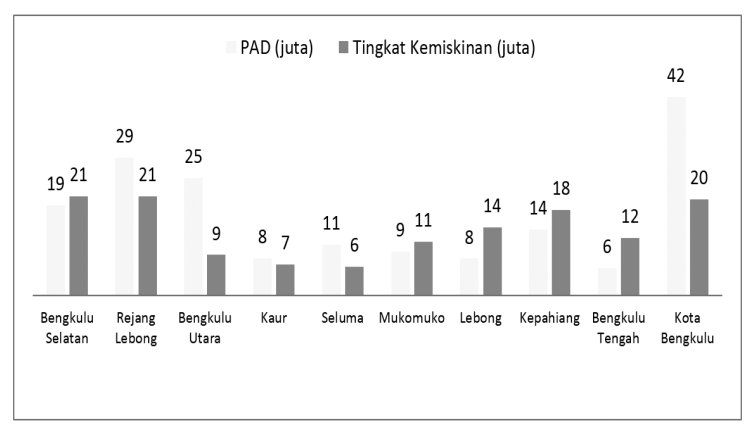

Gambar 3

$P A D$ dan Tingkat Kemiskinan

Pada Gambar 3 tersebut, terlihat di Kabupaten Bengkulu Selatan, Mukomuko, Lebong, Kepahiang dan Bengkulu Tengah memiliki PAD yang lebih rendah dibandingkan dengan tingkat kemiskinan. Jika dihubungkan kondisi ini dengan kapasitas fiskal, dimana kelima kabupaten tersebut, kecuali Bengkulu Selatan memiliki tingkat kapasitas fiskal yang tinggi terlihat bahwa peranan pemerintah Pusat di daerah ini masih sangat dominan.

Hanya Kota Bengkulu yang relatif mampu berkembang pada tingkat kapasitas fiskal yang rendah dengan PAD jauh melampau tingkat kemiskinan walaupun jumlah penduduk Kota Bengkulu tertinggi dibanding wilayah lain yang ada di Propinsi ini. Struktur ekonomi di Kota Bengkulu telah mampu mengubah wilayah ini menjadi pusat pertumbuhan di Propinsi Bengkulu dengan menjadi Kota Jasa, terlihat dari sektor perekonomiannya yang menjadi basis untuk sektor transportasi dan komunikasi, perdagangan, kKeuangan, jasa dan listrik, gas dan air bersih.

Tingginya ketergantungan pada bantuan dari Pemerintah Pusat di seluruh kabupaten/ kota mengharuskan Pemerintah Daerah untuk mampu menciptaan iklim investasi yang kondusif, sehingga menarik minat para investor, baik dari luar maupun dalam negeri (PMA dan PMDN) dan industri 
kecil maupun menengah diharapkan kondisi ini akan mendorong iklim usaha di wilayahnya.

Menurut Kinda (2008), yang menjadi kendala dari iklim investasi adalah infrastruktur fisik maupun keuangan, sumber daya manusia dan institusi daerah. Atas dasar itu dilakukan analisis untuk mengetahui faktor-faktor yang berpengaruh terhadap iklim investasi yang ada di Propini Bengkulu menggunakan analisis Regresi Logistik. Data yang dipergunakan berasal dari kuesioner yang disebarkan pada 33 responden.

Variabel bebas yang digunakan meliputi kemudahan mendapatkan lahan (Lhn), ketersediaan infrastruktur daerah (Inf), tingkat kesulitan dalam proses perizinan (IZ), kejelasan peraturan daerah (PD), transparansi biaya transaksi (TC), terhadap iklim investasi (CI). Sedangkan Iklim investasi dalam penelitian ini dijelaskan dengan menggunakan kategori $0=$ tidak kondusif, dan $1=$ kondusif.

Berdasarkan hasil analisis iklim investasi pada Tabel 16, terlihat bahwa variabel lahan, infrastruktur daerah, perizinan, peraturan daerah, biaya transaksi, secara simultan berpengaruh signifikan terhadap iklim investasi yang ada di Propinsi Bengkulu. Hal ini berarti para pembuat kebijakan, dalam hal ini Pemerintah Daerah, harus memerhatikan hal-hal yang berhubungan dengan kondisi ini.

Akses lahan yang dimaksud dalam penelitian ini adalah proses kemudahan untuk memperoleh lahan. Positifnya tanda menyatakan semakin mudah atau baik proses pengurusan lahan dalam artian proses pembebasan lahan, pengurusan sertifikat, kejelasan kepemilikan, maka akan semakin kondusif iklim investasi. Perubahan pada akses lahan mendorong pergerakan iklim investasi sebesar 2.238 kali lebih besar dibandingkan dengan pergerakan variabel lain.

Infrastruktur daerah pun memiliki tanda positif. Infrastruktur daerah yang dimaksudkan sebagai kemampuan dari pemerintah daerah menyediakan fasilitas sarana dan prasarana yang menunjang aktivitas investasi wilayah. Positifnya tanda antara insfrastruktur daerah dan iklim investasi dapat diartikan semakin baik kualitas infrastruktur daerah yang meliputi fasilitas jalan, jaringan telepon, listrik, air bersih, maka akan semakin kondusif iklim investasi yang ada di Propinsi Bengkulu.

Infrastruktur daerah adalah salah satu faktor penentu investor masuk ke suatu wilayah. Ottaviano (2008) menyatakan perbaikan infrastuktur memengaruhi distribusi geografis kegiatan ekonomi. Berdasarkan hasil estimasi, ternyata infrastruktur daerah yang dalam penelitian ini terdiri dari infrastruktur jalan, listrik dan air bersih memiliki pengaruh yang signifikan pada iklim investasi.

Berdasarkan data Badan Pusat statistik (BPS) Propinsi Bengkulu, panjang jalan nasional yang ada di propinsi ini dalam beberapa tahun terakhir tidak mengalami perubahan. Infrastruktur listrik pun berdasarkan laporan dari PLN 2014, konsumsi listrik per kapita terendah untuk tingkat Sumatera adalah Propinsi Bengkulu sebesar $283.41 \mathrm{kWh} /$ kapita. Infrastruktur dalam bentuk penyediaan air bersih pun di Bengkulu relatif masih rendah terlihat dari rendahnya pangsa sektor ini pada total PDRB Propinsi Bengkulu. Firdaus (2008) dalam Permana dan Alla (2010) menyatakan bahwa suplai tenaga listrik dan infrastruktur sosial berpengaruh signifikan terhadap daya tarik investasi pada suatu wilayah.

Perizinan memiliki koefisien bertanda negatif. Perizinan yang dimaksudkan disini

Tabel 5

Hasil Analisis Iklim Investasi di Propinsi Bengkulu

\begin{tabular}{|l|c|c|c|c|}
\hline \multicolumn{1}{|c|}{ Parameter } & Estimasi & Uji W & P value & Odd Ratio \\
\hline Akses Lahan & 0.806 & 6.112 & $0.013^{*}$ & 2.238 \\
Infrastruktur daerah & 0.580 & 3.774 & $0.052^{*}$ & 1.785 \\
Perizinan & -0.352 & 2.473 & 0.116 & 0.703 \\
Peraturan Daerah & -0.309 & 3.533 & $0.06 *$ & 0.734 \\
Biaya Transaksi & 0.349 & 3.281 & $0.07^{*}$ & 1.418 \\
Constanta & -19.049 & 5.623 & 0.018 & 0.000 \\
\hline Chi Square & 29.029 & & $0.000^{*}$ & \\
\hline
\end{tabular}

\footnotetext{
* signifikan pada $a=10 \%, * *$ signifikan pada $a=5 \%$,
} 
adalah pelaksanaan proses perizinan. Semakin sulit dan panjangnya waktu yang dibutuhkan dalam proses perizinan maka akan semakin rendah iklim investasi. Proses perizinan di beberapa kabupaten/kota sudah memakai metode Pelayanan Terpadu Satu Pintu, tetapi beberapa kabupaten masuh belum menerapkannya. Keputusan perizinanan terkadang masih sangat tergantung pada keputusan Kepala Daerah/ Bupati, sehingga waktu pengurusan dan biaya pengurusan agak sulit untuk diprediksi. Hal ini yang seringkali menjadi penyebab mundurnya investor di Propinsi Bengkulu.

Peraturan daerah memiliki tanda negatif. Peraturan daerah yang dimaksudkan disini adalah banyaknya peraturan daerah yang dikeluarkan oleh Pemerintah daerah, tingkat kesulitan pelaksanaan peraturan daerah. Negatifnya, tanda menyatakan semakin banyak peraturan daerah yang dikeluarkan maka semakin rendah atau tidak kondusif iklim investasi di Propinsi Bengkulu.

Artikel ini tidak membahas jumlah atau besaran nominal biaya transaksi yang dikenakan, melainkan membahas tentang transparansi dalam biaya transaksi. Positifnya tanda antara transparansi biaya transaksi dan iklim investasi menandakan semakin transparans proses pemungutan biaya transaksi maka akan semakin kondusif iklim investasi yang ada. Perkembangan sistem keuangan yang dikelola suatu wilayah berpengaruh positif pada jumlah investasi asing yang masuk yang pada akhirnya akan berimbas pada pertumbuhan ekonomi (Hermes dan Lensink, 2003).

Secara parsial, variabel kemudahan kepemilikan lahan, ketersediaan infrastruktur daerah, kejelasan peraturan daerah, transparansi biaya tansaksi berpengaruh secara signifikan pada iklim investasi sedangkan variabel lain belum berpengaruh secara signifikan. Hanya variabel perizinan yang belum memiliki pengaruh yang signifikan pada iklim investasi yang ada di Propinsi Bengkulu.

Sebagai masukan bagi para pembuat kebijakan, khususnya Pemerintah Daerah, maka kemudahan dalam proses kepemilikan lahan, kepemilikan fasilitas usaha, sertifikat, penyelesaian konflik kepemilikan, proses pelaksanaan jual beli lahan dan kelengkapannya adalah hal utama yang harus diperhatikan.

Hal ini sejalan dengan prioritas
Pemerintah Pusat untuk mendorong investasi dalam rangka pencapaian pertumbuhan ekonomi Indonesia. Bagaimanapun, faktorfaktor seperti desentralisasi, ketidakpastian hukum, dominasi kepentingan pribadi menjadikan iklim investasi menjadi sulit dan kompleks (Investment Climate Statement 2015). Pemerintah sangat membutuhkan kerjasama secara formal maupun informal dengan perusahaan yang ada di wilayahnya. Terdapat hubungan yang kuat antara korupsi, pembiayaan, kendala regulasi dan pajak, ketidakpastian kebijakan terhadap kinerja perusahaan yang berimbas pada pertumbuhan investasi dan aktivitas ekonomi suatu wilayah (Kauffman 2003).

Iklim investasi dapat didefinisikan sebagai lingkungan di mana perusahaan dan pengusaha dari kelompok memiliki kesempatan daninsentif untuk berinvestasi produktif, menciptakan lapangan kerja dan memperluas (Bank Dunia, 2005). Iklim investasi ini terdiri dari faktor lokasi tertentu yang membentuk lingkungan yang memungkinkan bagi perusahaan untuk berinvestasi produktif dan tumbuh (Smith dan Hallward, Driemeier, 2005)

Menurut penelitian yang dilakukan oleh Asian Development Bank (2005) ada 3 faktor utama yang mampu menciptakan iklim investasi yang kondusif, antara lain : (1) Kondisi ekonomi makro mencakup stabilitas ekonomi makro, keterbukaan ekonomi, persaingan pasar dan stabilitas sosial dan politik; (2) Kelembagaan, mencakup kejelasan dan efektivitas peraturan, perpajakan dan sistem hukum. Pada sektor keuangan, fleksibilitas pasar tenaga kerja yang terdidik dan terampil; (3) Infrastruktur mencakup sarana transportasi, telekomunikasi, listrik dan air. Hal ini sejalan dengan hasil penelitian yang menyatakan adanya pengaruh yang signifikan antara variabel infrastruktur daerah, peraturan daerah dan biaya transaksi terhadap iklim investasi di Provinsi Bengkulu.

Setelah diketahui faktor-faktor penentu iklim investasi, maka dapat dinyatakan bahwa iklim investasi akan kondusif jika seluruh faktor penentu iklim investasi berjalan baik. Sejalan dengan penelitian yang dilakukan oleh World Bank (2010) yang menyatakan bahwa pertumbuhan dan perkembangan sektor swasta yang optimal sangat membutuhkan institusi hukum yang dapat menjalin perlindungan atas property right, peraturan, regulasi dan biaya transaksi yang efisien dan transparan, kemampuan 
meminimalkan biaya transaksi yang harus ditanggung oleh perusahaan. Iklim investasi yang kondusif akan mendorong pertumbuhan ekonomi yang diharapkan suatu wilayah (Sinidra 2004).

\section{Simpulan dan Saran}

Artikel ini menghasilkan kesimpulan bahwa Propinsi Bengkulu masih harus mengutamakan sektor primer sebagai struktur utama perekonomiannya. Hal ini terbukti secara umum yang menjadi sektor basis di seluruh kabupaten/kota masih didominasi oleh sektor pertanian dan pertambangan.

Sektor konstruksi juga menjadi sektor basis dibanyak kabupaten/kota terbukti 6 dari 10 kabupaten/kota menjadikan sektor konstruksi sebagai sektor basis pada kabupaten tersebut dengan tingkat pertumbuhan yang cepat melebihi kondisi di Propinsi Bengkulu.

Sektor industri pengolahan hanya mampu menjadi sektor basis di Kabupaten Mukomuko dan Bengkulu Tengah. Sektor industri yang berkembang pun masih didominasi oleh industri rumah tangga berupa pengolahan hasil primer, belum mampu berkembang ke industri yang berskala besar.

Kabupaten yang memiliki kelebihan dalam hal sumber daya pertambangan ternyata belum mampu mendorong pertumbuhan ekonomi dan pendapatan per kapita. Terbukti dari kondisi kabupaten yang memiliki sektor basis di bidang pertambangan yaitu Kabupaten Bengkulu Utara, Bengkulu Tengah dan Seluma berada pada kelompok wilayah yang memiliki tingkat pertumbuhan ekonomi dan pendapatan per kapita yang rendah. Hal ini terjadi karena kabupatenkabupaten tersebut hanya dijadikan lokasi pertambangan semata, sedangkan aktivitas ekonomi perusahaan pertambangan tersebut tetap dipusatkan di Kantor pusat yang berada di Kota Bengkulu, telah terjadi kebocoran wilayah bahkan kabupatenkabupaten tersebut menjadi backwash bagi pusat pertumbuhan yaitu Kota Bengkulu sebagai ibukota Propinsi.

Tingginya tingkat ketergantungan seluruh kabupaten pada sumbangan dan bantuan yang berasal dari pemerintah pusat, terlihat dari rendahnya tingkat $P A D$, tingginya tingkat kemiskinan dan tingginya kapasitas fiskal. Hanya kota Bengkulu yang mampu meningkatkan PAD jauh melebihi tingkat kemiskinan dengan kapasitas fiskal yang rendah.

Dalam usahanya untuk meningkatkan iklim investasi yang kondusif di Propinsi Bengkulu maka hal utama yang harus diperhatikan, menurut para investor adalah proses kepemilikan lahan dan ketersediaan infrastruktur daerah dimana pada kenyataannya masih banyak terdapat tumpang tindih kepemilikan lahan, buruknya infrastruktur, ketidakjelasan dalam biaya transaksi atau pungutan liar (pungli) yang seringkali melebihi biaya resmi yang ditetapkan Pemerintah Daerah.

Berdasarkan hasil simpulan penelitian ini, Pemerintah Daerah diharapkan mampu mendorong investasi di sektor primer yaitu pertanian karena sektor perekonomian ini terbukti mampu menjadi sektor basis di hampir seluruh kabupaten/kota.

Sektor pertanian akan mampu berkembang jika didukung industri pengolahan hasil pertanian. Untuk itu, dibutuhkan suatu kebijakan yang mampu mensinergikan antara sektor pertanian dan industri pengolahan.

Selain itu, pemerintah hendaknya mampu mengkoordinasi aktivitas usaha dari para investor untuk meminimalisasi kebocoran wilayah dalam rangka mengatasi kondisi wilayah yang menjadi backwash bagi pusat pertumbuhan.

\section{Daftar Pustaka}

Al Khatib. H, Gassan SA, Samer MA, (2005). "Economical Determinant of domestic investment," European Scientific Journal Edition April Vol 8. No. 7.

Duadji, N. (2012). "Good Governance dalam Pemerintah Daerah " MIMBAR 28(2): 201-209.

Juanda, B.( 2009), Ekonometrika Permodelan dan Pendugaan, IPB Press, Bogor.

Hermes N, Lensink R. (2003). "Foreign Direct Investment, Financial Development and Economic Growth."Journal of Development Studies. Vol 38.

Karagol E, (2004). "A disaggregated analysis of government expenditure and private investment in Turkey," Jurnal of economic corporation, 25,2. Hal 134-144.

Kauffman BG, Stone AH, (2003). Investment Climate Arround the World: Voice of the firms from the world Bussines Environment Survey.

Kinda, T. (2008). Investment climate and FDI ini Developin Countries: Firm-Level Evidence. CERDI-CNRS. Universite D'auvergne CERDI-CNRS. 
Komite Pemantauan Pelaksanaan Otonomi Daerah, (2012). "Tata Kelola Ekonomi Daerah Tahun 2011." Asia Foundation.

Rustiadi E, Saefulhakim S, Panuju D R., (2009). Perencanaan dan Pengembangan Wilayah, Crestpent Press dan Yayasan Obor Indonesia, Jakarta.

Romer D. (2006). Advance Macroeconomics. New York, USA. McGraw-Hill/Irwin.

Saghi R, Azra K, (2012), Determinants of public and private Investment : An empirical Study of Pakistan, International Journal of Bussines and social Science Vol 3 No.4 Spesial Issue.

Sinidra F. (2004). Economic Growth: a Conducive Climate for Investment. Euromoney 35, 4-5.

Soelistijo, U. W. (2011). "Dinamika Penanaman Modal Asing (PMA) bidang Pertambangan
Umum di Indonesia." MIMBAR.

Todaro MP, Stephen CS, (2006). Pembangunan Ekonomi di Dunia Ketiga, Penerbit Erlangga, Jakarta.

Tolo, W. B. (2011). The Determinants of economic growth in the Philipines. V. Arora. Philipine, IMF Working Paper, Asia Pacific Department.

Undang-undang No. 20 tahun 2008 tentang Usaha Mikro, Kecil dan Menengah, Kementrian Negara Koperasi dan Usaha kecil dan Menengah Republik Indonesia tahun 2009. .

U.S. Department of State. (2015). Indonesia Investment Climate Investment 2015.

World Bank. (2003). Trade, Investment and Development in the Middle East North Africa: Engagging with The Wrld, World Bank, Washington DC. 